\section{Determinasi Kapitalisme Industri dalam Politik Penataan Ruang Perkotaan di Kabupaten Gresik}

Oleh:

\section{Galang Geraldy ${ }^{1}$}

\begin{abstract}
Abstrak
Morfologi atau kajian pembentukan ruang perkotaan di Kabupaten Gresik, Jawa Timur tak bisa dilepaskan dari sejarah berdirinya PT. Semen Gresik di tahun 1953 dan PT. Petrokimia Gresik di tahun 1972. Tingginya sirkulasi modal dan pertumbuhan ekonomi telah memicu industrialisasi selama empat dasawarsa terakhir di perkotaan Gresik. Determinasi kapitalisme industrialisasi telah menjadi lokomotif pembangunan kota sehingga menimbulkan kepadatan ruang dan ancaman degradasi ekologi.. Hasil penelitian menujukkan bahwa industrialisasi telah menjadi model pembangunan di Kabupaten Gresik karena menjadi penyumbang PDRB tertinggi selama bertahun-tahun. Pembangunan wilayah perkotaan Gresik lebih didominiasi oleh keberadaan pabrik-pabrik besar yang belum mampu dikendalikan dampak negatifnya oleh pemerintahan daerah. Akibatnya, perencanaan tata ruang lebih menitikberatkan pada akses-akses permodalan industri dengan pembangunan pabrik-pabrik khususnya di wilayah Gresik utara.
\end{abstract}

Kata kunci: tata ruang perkotaan, determinasi kapitalisme, industrialisasi

\footnotetext{
Abstract

The morphology or the study of the development of urban spatial management in Gresik, East Java cannot be inseparable

1 Galang Geraldy adalah staf pengajar pada Departeman Ilmu Politik Universitas PGRI Ronggolawe, Tuban, Jawa Timur. Penulis menyelesaikan studi S1 dan S2 Ilmu Politik di Universitas Airlangga, Surabaya.
}

from the history of establishment of corporations like PT. Semen Gresik in 1953 and PT. Petrokimian Gresik in 1972. The high circulation of capital and economic growth has fueled industrialization over the past four decades in the urban area of Gresik. The determination of capitalism through massive industrialization has become the main factor of the development of the city. However, such development has resulted in the density of the urban space and ecological degradation. This study shows that industrialization has become the solely model of development in Gresik due to its highest contribution to the region income over the years. Due to the fact that the construction of urban areas in Gresik is more dominated by the presence of large factories, their presence also created negative impacts which cannot be fully handle by the local governments. As a result, spatial planning of urban area is more focused on developing access for industrial capitals with more construction of building factories, especially in the northern region of Gresik

Keywords: urban spatial management, the determination of capitalism, industrialization

\section{Latar Belakang Masalah}

Sejarah mencatat pembangunan industri moderen pertama di Kabupaten Gresik di mulai sejak 1953 dengan berdirinya PT. Semen Gresik di kecamatan Kebomas dan dilanjutkan di tahun 1972 oleh berdirinya PT. Petrokimia Gresik di Kecamatan Gresik. Kehadiran dua industri besar tersebut menstimulasi berkembangnya ruang permukiman, pusat perdagangan dan sarana publik lainnya yang mendekati ruang industri tersebut. Akumulasi dari proses perkembangan tersebut adalah kepadatan ruang antara industri, 
Jurnal Pemikiran Sosiologi Volume 4 No. 1, Januari 2017

Galang Geraldy

Determinasi Kapitalisme Industri dalam Politik Penataan Ruang Perkotaan di Kabupaten Gresik

permukiman dan pusat perdagangan wilayah Kecamatan Gresik dan perluasan wilayah Kecamatan Kebomas. Pertumbuhan ekonomi yang cukup tinggi dan tingkat urbanisasi yang kian meningkat menjadikan kedua wilayah ini menjadi sentra pembangunan. Hal inilah yang lantas menjadi salah satu alasan terpenting berdirinya Gresik secara otonom menjadi sebuah kabupaten yang terpisah dari Kabupaten Surabaya di tahun $1974 .^{2}$ Di dalam perkembangan pembangunan di perkotaan selama empat dasawarsa terakhir, laju industrialisasi semakin menunjukkan tren yang pesat. Secara tidak langsung, hadirnya dua industri besar (BUMN) di atas turut memberikan dampak berkembangnya industri-industri lain baik itu sebagai industri penyangga maupun industri lain yang berbeda.

Kuantitas industri di kawasan perkotaan Kabupaten Gresik yang melingkupi kecamatan Gresik berjumlah 304 industri, kecamatan Kebomas berjumlah 2.043 industri, kecamatan Manyar berjumlah 556

2 Pada awal kemerdekaan, Gresik masih merupakan kota kawedanan dibawah Kabupaten Surabaya, dimana pada saat itu Kota Surabaya merupakan Kota Praja (Geemente).Di masa Orde Baru, Kabupaten Surabaya dirubah menjadi Kabupaten Gresik dengan ibu kota Gresik. Perubahan tersebut berdasarkan Peraturan Daerah Nomor 2 DPRD-II/1974, tanggal 20 Maret 1974, dikuatkan oleh Peraturan Pemerintah Nomor 30 tahun 1974, tanggal 1 November 1974. Peraturan ini menetapkan pengalihan status nama Kabupaten Surabaya menjadi Kabupaten Gresik, beribu kota di Gresik sejak tanggal 27 Februari 1974. industri dan di kecamatan Duduk Sampeyan berjumlah 321 industri di berbagai jenis (KDA:2014). Diantaranya beberapa industri berpotensi risiko tinggi seperti PT. Petrokimia Gresik dan PT. Nippont Paint di Kecamatan Gresik, PT. Semen Gresik dan PT. Nusantara Plywood di Kecamatan Kebomas dan PT. Wings Surya dan PT. Maspion Grup yang berada di Kecamatan Manyar. Konsekuensi perkembangan ruang industrialisasi yang kian tinggi adalah munculnya ruang-ruang permukiman dan sarana publik lainnya yang mendekati ruang industri. Anomali ruang perkotaan di dominasi industri, permukiman dan sarana publik lainnya berada dalam satu zona yan saling berdekatan tanpa adanya zona penyangga (buffer zone) dan ruang terbuka hijau (green belt).

Beberapa permasalahan tata ruang industri dan permukiman yang pernah terjadi adalah sebagai berikut. Peristiwa ledakan di PT. Petrowidada pada bulan Januari dan April tahun 2004. Kedua peristiwa ini menyebabkan keresahan warga kelurahan Meduran, dan perumahan Gresik Kota Baru yang sangat berdekatan dengan lokasi pabrik. Kedua, peristiwa di bulan Februari 2006 yaitu ledakan yang terjadi di pabrik Unit I PT. Petrokimia Gresik. Ledakan itu dirasakan dampaknya sampai pemukiman desa Sidomukti, Kebomas dan warga di perumahan Gresik Kota Baru dalam radius $2 \mathrm{~km}$ dari lokasi pabrik 
Jurnal Pemikiran Sosiologi Volume 4 No. 1, Januari 2017

Galang Geraldy

Determinasi Kapitalisme Industri dalam Politik Penataan Ruang Perkotaan di Kabupaten Gresik

tersebut. Ketiga di bulan Oktober 2011, sebuah pabrik pengolahan dan penyulingan oli bekas di Primergy Oil Station kawasan industri Gresik (KIG) terbakar yang lokasinya tak jauh dari permukiman warga. Di bulan Mei 2012 penduduk di kelurahan Tlogopojok yang melakukan demo di DPRD pada atas dampak polusi udara dari PT. Petrokimia Gresik yang mereka rasakan. November 2012, sekitar seribu warga Perumahan Gresik Kota Baru (GKB) turun ke jalan, memprotes pembangunan perluasan lahan pabrik milik PT Intan Ustrix di kawasan pemukiman GKB.

Beberapa peristiwa tersebut menunjukkan ruang perkotaan tidak teratur dalam dimensi berkelanjutan. Lokus pembangunan ekonomi menjadi basis utama dalam menentukan dan mengendalikan ruang perkotaan Gresik. Di dalam hal ini, ekspansi akumulasi modal industrialisasi menjadi penentu kebijakan tata ruang perkotaan Gresik. Implikasinya nyata, ekologi dan sosial masyarakat menjadi korban pembangunan.

\section{Metodologi Penelitian}

Penelitian ini menggunakan metode kualitatif dengan tipe deskriptif. Hal ini untuk menunjang riset yang lebih mendalam dalam menganalisa persoalan tata ruang perkotaan kabupaten Gresik dalam perpsektif politik tata ruang. Metode kualitatif lebih mengedepankan pencarian atas apa yang disebut makna (meanings) melalui proses-proses eksplorasi tanpa henti (never ended exploration) karena masyarakat sebagai sistem sosial yang terus berubah menghasilkan realitas-realitas yang bersifat kontinyu (Usman dkk:1996;74-80) Unit analisis dalam penelitian ini adalah mengkaji secara analitik faktor politik kapitalisme yang melatarbelakangi perkembangan industri di perkotaan Kabupaten Gresik.

Informan penelitian ini meliputi berbagai macam, seperti (1) informan kunci (key informan), yaitu mereka yang yang mengetahui dan memiliki berbagai informasi pokok yang diperlukan dalam penelitian, (2) informan utama, yaitu mereka yang terlibat langsung dalam interaksi sosial yang diteliti, (3) informan tambahan, yaitu mereka yang dapat memberikan informasi walaupun tidak langsung terlibat dalam interaksi sosial yang diteliti. Terkait penelitian ini, maka sebagai informan kunci dan utama adalah pemerintahan daerah yaitu SKPD Bappeda, Dinas Tata Ruang, Dinas Industri dan Perdagangan dan Dinas Perizinan dan Penanaman Modal, pelaku industri yaitu Kawasan Indusstri Gresik dan Kawasan Industri Maspion, dan masyarakat sekitar kawasan industri.

Data primer penelitian ini adalah wawancara secara langsung kepada pemerintahan daerah yang terkait dalam 
Jurnal Pemikiran Sosiologi Volume 4 No. 1, Januari 2017

Galang Geraldy

Determinasi Kapitalisme Industri dalam Politik Penataan Ruang Perkotaan di Kabupaten Gresik

penataan ruang industri, perizinan industri dan perencanaan pembangunan industri. Wawancara juga dilakukan kepada masyarakat sekitar industri seperti di Kelurahan Roomo dan Indro (Suyanto dkk:2006-38)

Data sekunder dapat diperoleh dari sumber data tertulis dan foto pemetaan. Data tertulis dapat berupa dokumentasi resmi pemerintah, perda kebijakan industrialisasi, dan pemberitaan di media massa. Foto berupa gambar industrialisasi dan pemetaan zonasi industrialisasi.

Penelitian ini menggunakan dua macam pengumpulan data secara kualiatif, yakni indepth interview( wawancara mendalam ) dan penelaahan terhadap dokumen tertulis. Pertama adalah wawancara mendalam (indepth interview) dan terbuka. Data yang diperoleh terdiri dari kutipan langsung dari orang-orang tentang pengalaman, pendapat, perasaan, dan pengetahuannya. Penulis melakukan wawancara dengan informan kemudian mencatat dan mentranskrip percakapan atau informasi yang dibutuhkan. Dalam melakukan wawancara dengan informan, penulis menggunakan tape-recorder sebagai alat untuk merekam pembicaraan selama proses wawancara berlangsung. Kedua, penelaahan terhadap dokumen tertulis. Data yang diperoleh dari metode ini berupa cuplikan, kutipan, atau penggalan-penggalan dari catatancatatan organisasi, klinis, atau program; memorandum-memorandum dan korespondensi; terbitan dan laporan resmi. Terdapat tiga jalur analisa data kualitatif yaitu reduksi data, penyajian data, dan penarikan kesimpulan (Miles dan Huberman, 1992). Proses reduksi data menyangkut seleksi tehadap berbagai data yang telah diperoleh melalui tahapan sebelumnya sehingga menjadi data yang relevan dengan unit analisis penelitian. Penyajian data berupa deskripsi gagasangagasan yang diperoleh dari informan dikaitkan dengan kerangka konseptualisasi dan teoritisasi. Gagasan tersebut di tunjang dengan dokumentasi baik berupa perda, tabel dan data-data yang memiliki validitas.

\section{Hasil Penelitian}

\section{Perkembangan Perkotaan Gresik}

Perkembangan awal Kabupaten Gresik dimulai di sekitar pelabuhan Kota Gresik hingga ke arah Alun-alun Gresik di sebelah barat. Pelabuhan Kota Gresik ini pada abad 14 menjadi pintu masuk lalu lintas perdagangan dan selanjutnya penyebaran agama Islam di Pulau Jawa. Selanjutnya perkembangan kota berlangsung secara radial, menjari mengikuti jaringan jalan arteri Gubernur Suryo ke arah Manyar dan Jalan Pahlawan, Jalan Veteran ke arah Selatan. Namun pada saat pelabuhan perdagangan dipindah ke Surabaya, kota Gresik mengalami kemunduran, dan 
Jurnal Pemikiran Sosiologi Volume 4 No. 1, Januari 2017

Galang Geraldy

Determinasi Kapitalisme Industri dalam Politik Penataan Ruang Perkotaan di Kabupaten Gresik

pertumbuhannya cenderung stagnan. Hal

ini berlangsung hingga tahun 1950, masa ini

disebut sebagai masa pra-industrialisasi

dimana kota Gresik mengalami stagnasi

pertumbuhan hingga kehilangan statusnya

sebagai ibukota Kabupaten. Karena faktor

stagnasi pertumbuhan maka sampai pada

awal kemerdekaan, Gresik masih

merupakan kota kawedanan dibawah kota

Surabaya, dimana pada saat itu kota

Surabaya merupakan Kota Praja

(Geemente).

Fase kedua dari perkembangan kota Gresik adalah diawali dari berkembangnya Kawasan PT. Semen Gresik di tahun 1953 dan PT. Petrokimia Gresik di tahun 1972 yang berperan dalam membentuk struktur ruang kota Gresik. Keberadaan dua kawasan industri yang berskala nasional tersebut, menyebabkan pertumbuhan Kota Gresik meningkat pesat, terutama disekitar dua kawasan industri tersebut. Pada akhirnya kota Gresik yang semula hanya berkembang di sekitar alun-alun dan pelabuhan Gresik, juga berkembang di sekitar dua kawasan industri tersebut sehingga terbentuk tiga kluster pertumbuhan yaitu, sekitar alun-alun, sekitar PT. Semen Gresik dan sekitar PT. Petrokimia Gresik.

Fase terakhir dari perkembangan perkotaan adalah dengan berkembangnya konsep kota baru di Kebomas. Muncullah zonasi permukiman-permukiman moderen dengan konsep kota baru yang mandiri. Pada dasarnya arah pertumbuhan perkotaan cenderung bergerak ke arah barat, mengikuti jalur jalan arteri ke arah kecamatan Duduk Sampeyan dan ke arah utara ke arah kecamatan Manyar.(Bappeda Gresik:2014) 


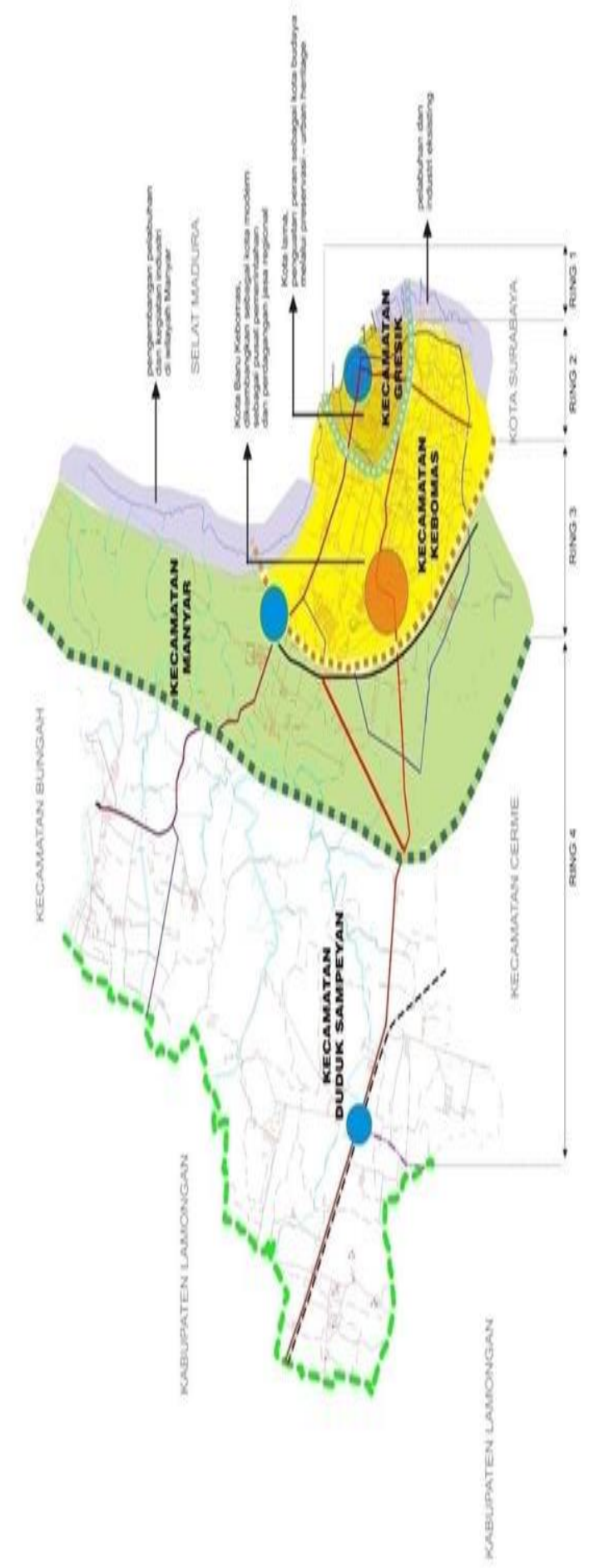

Gambar 1. Konsep Sturktur Ruang Makro Kecamatan di Perkotaan Kabupaten Gresik (sumber: Kecamatan Dalam Angka 2012, Bappeda Kabupaten Gresik)

\section{Ruang Industrialisasi Perkotaan}

Industrialisasi merupakan salah satu model pembangunan di negara-negara berkembang yang mengejar optimalisasi pertumbuhan ekonomi. Industri merupakan salah satu variabel pendorong perubahan sosial yang dominan dalam abad-abad terakhir sehingga kehadirannya akan memunculkan apa yang dinamakan sebagai masyarakat industri yang berlawanan dengan masyarakat agraris.

Laju industrialisasi selalu bersamaan dengan urbanisasi sehingga dalam perkembangannya akan membentuk kepadatan kota. Kedatangan penduduk yang memadatai pusat-pusat industri akan menciptakan perluasan kota lebih lanjut (Horton, 1984:137). Fenomena inilah yang terjadi selama empat puluh tahun terakhir di kabupaten Gresik, dimana industrialisasi sedang mengalami fase ekspansi yang masif di berbagai wilayah perkotaan.

Rencana Penggunaan Lahan Kabupaten Gresik ditetapkan sebagai berikut :

- Kawasan Permukiman; direncanakan sebesar 15.643 Ha dengan 7,53\% (1822,97 ha) direncanakan di wilayah kecamatan Kebomas dan 0,97\% (235,79 ha) dan di wilayah kecamatan Gresik Salah satu kawasan permukiman yang akan berkembang di kecamatan Kebomas adalah permukiman di areal konservasi bukit hollywood sekitar 70 ha. Pada lahan ini, karena sekaligus 
Jurnal Pemikiran Sosiologi Volume 4 No. 1, Januari 2017

Galang Geraldy

Determinasi Kapitalisme Industri dalam Politik Penataan Ruang Perkotaan di Kabupaten Gresik

berfungsi sebagai perlindungan

kawasan di bawahnya dengan tingkat kelerengan sekitar $30-40 \%$, perlu diperhatikan persyaratan KDB sebesar maksimal $40 \%$ untuk kawasan ini. Secara keseluruhan, kecamatan Kebomas akan menampung $31.704 \mathrm{KK}$ pada tahun 2014, dengan tingkat kepadatan sedang.

- Kawasan Industri; penggunaan lahan bagi industri di kabupaten Gresik direncanakan 9,81 \% dari luas lahan atau 11.728 ha, dan diprioritaskan berada di kecamatan Ujungpangkah, Manyar dan Sidayu dengan luas berkisar antara 1.000 - 4.000 ha. Khusus untuk kecamatan Gresik dan Kebomas, hanya dialokasikan sebesar $1,43 \%$ dari total alokasi peruntukan industri, yaitu sebesar 23,95 ha di Gresik dan 100,05 ha di Kebomas. Pengembangan industri di kecamatan Gresik dan Kebomas lebih didorong bagi pengembangan Industri kecil dan menengah, yaitu berupa industri bordir, konveksi, kopiah, dan tas/dompet di kecamatan Gresik (kelurahan Trate, kelurahan Pekauman, kelurahan Sidokumpul, kelurahan Sukodono, kelurahan Gapurosukolilo, dan kelurahan Pakelingan) dan industri kerupuk, pande besi, alat dapur, kemasan, bordir, tempe, dan perhiasan imitasi di kecamatan Kebomas (kelurahan Sidomukti, Kawisanyar, Klangonan, Giri dan Sekarkurung).

- Kawasan Pertambangan; arahan pemanfaatan ruang bagi kawasan pertambangan di kecamatan Gresik dan kecamatan Kebomas adalah lebih pada reklamasi lahan pasca penambangan, yaitu berupa :

- Pemanfaatan lahan pasca penambangan yang memiliki morfologi berbentuk dataran atau kemiringan rendah menjadi areal permukiman dan kawasan industri. Misalnya Kawasan Industri Gresik dan Perumahan Gresik Kota Baru (GKB) di lahan pasca penambangan oleh PT Semen Gresik;

- Pemanfaatan lahan pasca penambangan yang memiliki morfologi berupa cekungan menjadi penampung air hujan. Waduk dan telaga yang terbentuk dapat menjadi penyeimbang hidrogeologi air tanah, sumber air, dan kawasan wisata air. Kawasan wisata telaga Ngipik adalah contoh pengembangan lahan pascapertambangan menjadi kawasan wisata andalan;

- Pemanfaatan lahan pascapenambangan yang disertai penghijauan atau reboisasi. 
Jurnal Pemikiran Sosiologi Volume 4 No. 1, Januari 2017

Galang Geraldy

Determinasi Kapitalisme Industri dalam Politik Penataan Ruang Perkotaan di Kabupaten Gresik

- Kawasan Pariwisata; kegiatan wisata di kecamatan Gresik direncanakan termasuk pada kegiatan wisata budaya, yaitu berupa Makam Sunan Giri, Makam Maulana Malik Ibrahim, Makam Raden Santri, Makam Nyi Ageng Pinatih dan Makam Siti Fatimah binti Maimun.

\begin{tabular}{|l|l|l|}
\hline \multicolumn{3}{|l|}{ Rencana Penggunaan Lahan Kecamatan } \\
\hline Luas (Ha) & Kebomas & Gresik \\
\hline Luas Wilayah & 3.433 & 799 \\
\hline Pemukiman & 1.823 & 236 \\
\hline Industri Jasa & $1.065,82$ & 154,59 \\
\hline $\begin{array}{l}\text { Fasum, } \\
\text { \&Perdagangan }\end{array}$ & 122 & 118 \\
\hline $\begin{array}{l}\text { Kebun } \\
\text { Campuran }\end{array}$ & 242 & 10 \\
\hline RTH & 51 & 12 \\
\hline $\begin{array}{l}\text { Sempadan } \\
\text { Jalan }\end{array}$ & 1.096 & 186 \\
\hline Lain-Lain & & 214 \\
\hline
\end{tabular}

Tabel.1 Luas Wilayah Zonasi Ruang dan Rencana Penggunaan Lahan di Kecamatan Kebomas dan Gresik, Kabupaten Gresik (Sumber: Kecamatan Dalam Angka 2012. Bappeda Kabupaten Gresik)

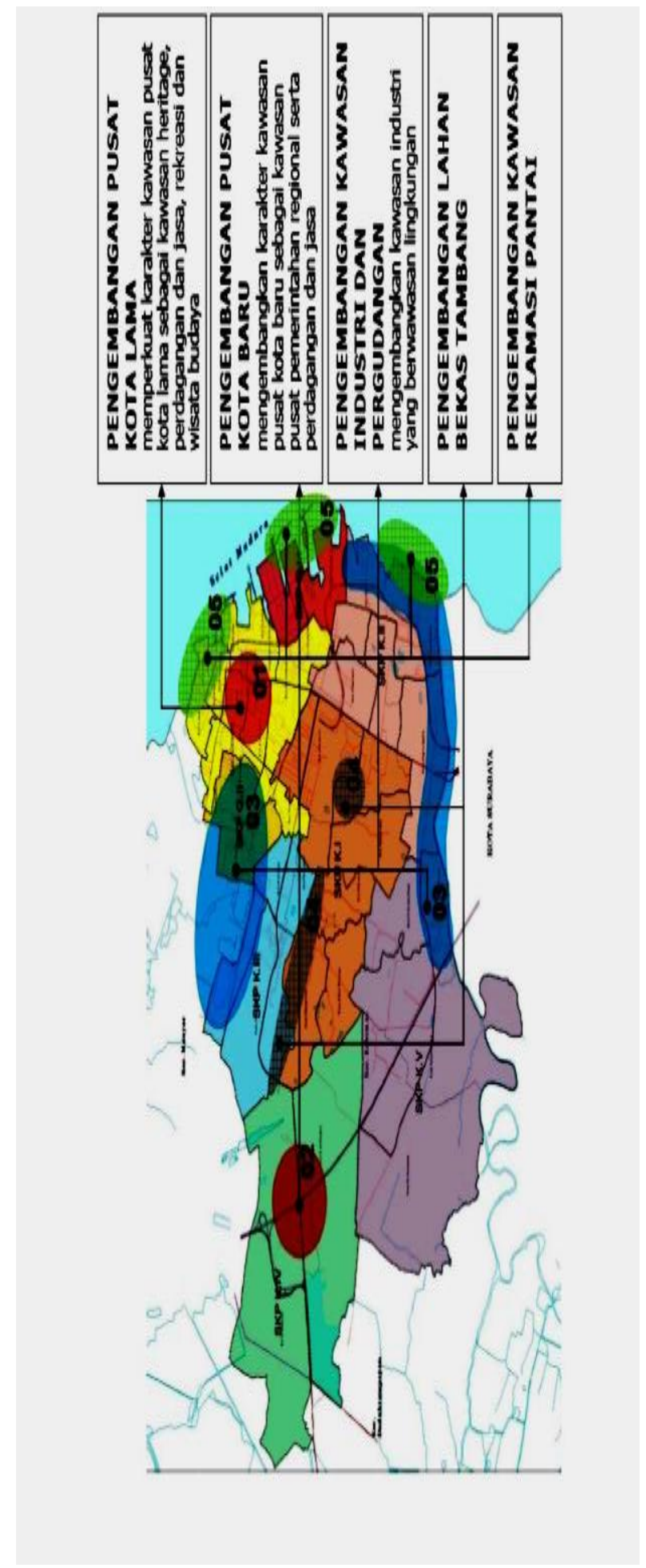

Gambar 2. Peta Pola Peruntukkan Lahan Perkotaan (Sumber: Perda No. 8 Tahun 2011 tentang Rencana Detail Tata Ruang Kabupaten Gresik 2011-2030) 
Jurnal Pemikiran Sosiologi Volume 4 No. 1, Januari 2017

Galang Geraldy

Determinasi Kapitalisme Industri dalam Politik Penataan Ruang Perkotaan di Kabupaten Gresik

\section{Klasifikasi Ruang Industri Perkotaan}

Kawasan industri di kecamatan Gresik dan

Kebomas direncanakan terdiri dari zona industri besar polutan, zona industri besar non polutan, zona industri kecil polutan, zona industri kecil non polutan, zona pergudangan tertutup dan zona pergudangan terbuka/depo.

\section{a. Zona Industri Besar Polutan}

Persyaratan peruntukan kegiatan industri besar polutan banyak ditekankan pada aspek pengamanan lingkungan hidup, mengingat kegiatan industri besar polutan sangat berisiko pada dampak lingkungan yang ditimbulkannya. Dari sisi kapasitas serta skala kegiatan produksi, industri besar merupakan industri yang menyerap tenaga kerja cukup besar yaitu sekitar 100 orang, sehingga faktor aksesibilitas sangat perlu diperhatikan dalam penempatan lokasi industri besar. Jumlah tenaga kerja yang cukup banyak dengan skala produksi yang cukup besar mensyaratkan industri besar perlu ditempatkan pada suatu lokasi yang mudah dijangkau namun jauh dari kawasan permukiman, yaitu berada tidak jauh dari akses jaringan jalan kolektor yang terkoneksi dengan jaringan jalan arteri. Sedangkan risiko pencemaran akibat limbah polutan yang dihasilkan, mensyaratkan lokasi industri besar polutan harus ditempatkan pada lokasi yang dekat dengan wilayah aliran sungai dengan terlebih dahulu dilakukan pengolahan limbah pada masing-masing zona industri.

Dengan persyaratan sebagaimana disebutkan diatas, hingga akhir tahun perencanaan Zona Industri Besar Polutan diarahkan menempati wilayah yang saat ini telah berkembang dengan kegiatan industri besar yaitu pada wilayah sekitar Kali Lamong di SKP IV Kebomas dan SKP V Kebomas. Berdasarkan pertimbangan tersebut, hingga akhir tahun perencanaan, Zona Industri Besar Polutan dialokasikan sebesar 181,46 ha atau mencapai 5,01 \% dari luas kecamatan Gresik dan Kebomas.

\section{b. Zona Industri Besar Non Polutan}

Industri besar non polutan merupakan kegiatan industri berskala besar dengan tenaga kerja yang cukup banyak. Seperti halnya industri besar polutan, arahan lokasi dari industri besar non polutan adalah pada lokasi yang mudah dijangkau, berada tidak jauh dari jaringan jalan kolektor, yang membedakan adalah industri besar polutan tidak perlu harus berada pada wilayah yang dekat dengan sungai. Berdasarkan persyaratan lokasi tersebut, Zona Industri Besar non Polutan diarahkan untuk dikembangkan pada wilayah yang saat ini telah eksis sebagai industri besar yaitu pada SKP II Kebomas, SKP III Kebomas, SKP IV Kebomas dan SKP V Kebomas. Berdasarkan pertimbangan tersebut, hingga akhir tahun perencanaan, Zona Industri Besar Non Polutan dialokasikan sebesar 382,03 ha 
Jurnal Pemikiran Sosiologi Volume 4 No. 1, Januari 2017

Galang Geraldy

Determinasi Kapitalisme Industri dalam Politik Penataan Ruang Perkotaan di Kabupaten Gresik

atau $10,73 \%$ dari luas kecamatan Gresik dan Kebomas.

\section{c. Zona Industri Kecil Polutan}

Industri kecil merupakan kegiatan industri yang hanya memperkerjakan sekitar 5-20 orang dengan aktivitas produksi tidak setinggi industri besar. Mengingat jenis kegiatannya yang spesifik dan berisiko terhadap kenyaman lingkungan hunian, industri kecil disyaratkan tidak berlokasi di kawasan permukiman. Berbeda dengan industri besar, penempatan lokasi industri kecil dapat tidak disekitar jalan arteri atau jalan kolektor. Mengingat aktivitas produksi dari industri kecil polutan berisiko terhadap pencemaran lingkungan akibat limbah buangan yang dihasilkan, lokasi industri kecil polutan disyaratkan berada dekat dengan sungai untuk mempermudah proses pembuangan limbah yang telah diolah. Hingga akhir tahun perencanaan, Zona Industri Kecil Polutan dialokasikan sebesar 17,66 ha atau $0,50 \%$ dari luas kecamatan Gresik dan Kebomas.

\section{d. Zona Industri Kecil Non Polutan}

Seperti halnya industri kecil polutan, penempatan industri kecil non polutan disyaratkan pula berada jauh dari lingkungan permukiman dan didukung oleh jaringan jalan lokal. Namun demikian mengingat aktivitas produksinya yang tidak terlalu berisiko terhadap pencemaran lingkungan, penempatan lokasi industri kecil non polutan disyaratkan dapat tidak berdekatan dengan sungai. Hingga akhir tahun perencanaan, Zona Industri Kecil Non Polutan dialokasikan sebesar 0.54 ha atau 0,02\% dari luas kecamatan Gresik dan Kebomas

\section{e. Zona Pergudangan Tertutup}

Pergudangan tertutup merupakan aktivitas yang menyertai keberadaan sebuah industri besar dan industri kecil, baik polutan maupun non polutan. Mengingat aktivitas bongkar muat yang sangat menunjang proses produksi, zona pergudangan tertutup dialokasikan berada di dekat zona industri besar/kecil baik polutan maupun non polutan yang didukung pula oleh akses jaringan jalan yang baik. Khusus untuk pergudangan bahan kimia dan berbahaya, disyaratkan berlokasi jauh dari permukiman penduduk. Hingga akhir tahun perencanaan, Zona Pergudangan Tertutup dialokasikan sebesar 40,84 ha atau 1,15\% dari luas kecamatan Gresik dan Kebomas.

\section{f. Zona Pergudangan Terbuka/Depo}

Pergudangan terbuka / depo disyaratkan berada dekat dengan lokasi industri besar/kecil dan berada dekat jaringan jalan arteri kolektor serta berlokasi jauh dari permukiman penduduk. Hingga akhir tahun perencanaan, Zona Pergudangan Terbuka dialokasikan sebesar 7,70 ha atau $0,22 \%$ dari luas kecamatan Gresik dan Kebomas. 
Jurnal Pemikiran Sosiologi Volume 4 No. 1, Januari 2017

Galang Geraldy

Determinasi Kapitalisme Industri dalam Politik Penataan Ruang Perkotaan di Kabupaten Gresik

Analisa Data: Dominasi Ekonomi Industri dan Hegemoni Kapitalisme atas Ruang

Sejak proyek neoliberalisme dipompakan masuk sebagai langkah penyelamatan krisis kapitalisme Asia Tenggara di akhir dekade 1990-an, terjadi perubahan peta penguasaan kapital. Kapital global (global capital), kapital industri (industrial capital) dan kapital keuangan (finance capital) mengalir masuk. Maka sentralisasi kapital sedang terjadi secara global, mengambil bentuk, di antaranya, melalui integrasi vertikal perusahaan-perusahaan besar dan korporasi-korporasi multinasional. Hasilnya, dalam konteks politik ruang, kapitalisme mengambil bentuk dan hegemoni ruang-ruang kota atau kebijakan penataan ruang kota tendensi terhadap kepentingan-kepentingan kapitalisme.

Pemikir klasik arsitektur kota, Aldo Rossi, dalam bukunya The Architecture of the City (1966) menyebutkan bahwa kekuatan ekonomi menjadi determinan dalam transformasi sebuah kota. Disinilah paradoks pembangunan kota seringkali terjadi, ketika determinasi ekonomi sangat tinggi sehingga menegasikan dimensidimensi yang lain yaitu ekologi dan sosial. Di dalam setiap kebijakan pembangunan dan penataan ruang kota faktor ekonomi menjadi landasan utama. Begitu halnya dengan penataan ruang kota di kabupaten Gresik. Secara umum terdapat dua permasalahan penting dalam penataan ruang perkotaan di kabupaten Gresik.

Pertama, terlalu dominannya pembangunan yang bertumpu pada aspek pertumbuhan ekonomi dalam pembangunan kota. Indikasinya adalah melepaskan kebijakan tata ruang kota pada mekanisme pasar dan kekuatan kapitalisme seperti pemberian keleluasaan industri-industri besar dalam memilih lahan di dalam perkotaan. Tata ruang kota menjadi ajang perebutan bagi hegemoni kapitalisme. Tata ruang kota menyimpulkan eksistensi kapitalisme dalam memproduksi ruang (Lefebvre:1991), sehingga ruang menjadi ajang komoditas yang mengalienasi kepentingan-kepentingan diluar ekonomi seperti ekologi dan sosial. Di wilayah kelurahan Roomo sampai Sukomulyo, kecamatan Manyar, terdapat puluhan industri berat. Sepanjang jalan utama di wilayah tersebut, berjejer industri-industri besar dengan tingkat polutan udara yang tinggi.

Kasus-kasus serupa seringkali terjadi dan berakhir pada kompensasi dari industri yang bersangkutan. Akbatnya permasalahan yang substansial yaitu penataan ruang industri dan permukiman belum terpecahkan. Tata ruang kota yang lebih didominasi industrialisasi adalah potret dimana kebijakan pembangunan berada pada poros mengejar pertumbuhan ekonomi dalam bingkai skenario 
Jurnal Pemikiran Sosiologi Volume 4 No. 1, Januari 2017

Galang Geraldy

Determinasi Kapitalisme Industri dalam Politik Penataan Ruang Perkotaan di Kabupaten Gresik

kapitalisme. Determinasi kapitalisme masuk ke dalam politik kebijakan pemerintahan daerah. Politik desentralisasi seharusnya menjadi legitimasi kewenangan pemerintahan daerah untuk menentukan tata ruang kota yang partisipatoris dan humanis. Otonomi daerah yang menghasilkan pemilihan secara langsung dari penduduk kabupaten Gresik seharusnya menjadi bentuk sinergisitas yang baik antara warga dengan pemerintah. Maka kebijakan penataan ruang seharusnya melibatkan seluas-luasnya warga untuk turut serta sehingga terjalin aspek-aspek pembangunan yang berkelanjutan.

Pada kenyataannya, acapkali hal itu terabaikan. Peneliti ketika mewawancarai salah satu ketua RW yang menjabat selama 23 tahun dan salah satu tokoh pemuda di desa Roomo menyatakan sebagai berikut;

"Pemerintah justru belum pernah mengajak kami untuk berbicara soal tata ruang di sini. Pabrik Petro Jordan yang berdiri baru-baru ini tepat di belakang rumah kami kita tidak tahu. Yang kami tahu pabrik itu jelas memiliki potensi bahaya yang lebih besar dari PT. Smelting yang baru-baru ini bocor. Penghijauan di pinggir jalan raya yang seharusnya menjadi penyaring polutan udara justru tidak ada."

(Sumber data primer: wawancara)
Merujuk pada pemikiran Noorena Hertz (2003), bahwa pemerintahan saat ini lebih memilih bersekutu dengan para pemilik modal yang minoritas di banding publik secara mayoritas. Di saat itulah sistem dan pratik politik didominasi oleh kepentingan kelompok dan perseorangan yang memiliki akses modal yang kuat. Implikasinya tata ruang kota diwujudkan dengan pembangunan yang berorientasi pada keuntungan (profit), pertumbuhan dan akumulasi ekonomi yang tinggi. Mereka jelas mengabaikan dimensi-dimensi ekologis dan sosial yang dianggapnya tak linear dengan investasi ekonomi. Pembangunan yang mensyaratkan ketersediaan ekologi dan keterlibatan sosial masyarakat hanya akan membuang waktu dan investasi ekonomi yang maksimal. Itulah logika neoliberalisme yang kini menghinggapi dalam kebijakan tata ruang kota. Kedua, ketidaksiapan perangkat manajemen kota dalam menghadapi proses perkembangan kota yang begitu cepat dan cenderung liar (Santoso, 2006:90).

Tak lepas dari faktor pertama di atas, bahwa ekspansi ekonomi kapitalisme memang menjanjikan dan menghadirkan pembangunan kota yang serba instan. Pembangunan pusat pertumbuhan ekonomi seperti mall, industri, pusat perdagangan dan lain-lain jelas akan memberikan dampak persebaran ekonomi di sekitarnya (trickle down effect) dan hal ini tak perlu 
Jurnal Pemikiran Sosiologi Volume 4 No. 1, Januari 2017

Galang Geraldy

Determinasi Kapitalisme Industri dalam Politik Penataan Ruang Perkotaan di Kabupaten Gresik

memakan waktu yang lama. Namun dibalik ekspansi pembangunan yang serba cepat dan tak terkendali ini justru menyebabkan kota tanpa arah dan mengalami kepadatan dalam waktu yang singkat. Analisa permasalahan tata ruang secara umum di banyak kota di Indonesia di atas merupakan gambaran secara riil yang ada di Kabupaten Gresik.

Ijin perubahan alih fungsi lahan untuk dijadikan industri semakin meningkat dalam lima tahun terakhir. Seperti yang dijelaskan oleh Kepala Bagian Tata Ruang Dinas Pekerjaan Umum:

"Untuk ke depan industrialisasi akan kami rencanakan ke wilayah Kecamatan Manyar yang notabenenya masih banyak pertanian yang kami rasa sudah tidak cocok lagi. Industrialisasi akan masuk ke sana dengan harapan pertumbuhan ekonomi dapat segera muncul di sana."

(Sumber data primer: wawancara)

Di tempat terpisah, peneliti mewawancarai salah seorang pemangku otoritas dari Badan Lingkungan Hidup Bidang Pengendalian dan Pencemaran Lingkungan,

"Saat ini yang seringkali terjadi adalah misskoordinasi atau tiap SPKD memiliki kepentingan masingmasing yang terkadang tidak bisa mengakomodasi semua kepentingan. Industri-industri yang banyak itu kan untuk pembangunan kota maka Bappeda dan Penanaman Modal."

(Sumber data primer: wawancara)

Hal diatas menjadi fenomena ketidakmampuan pemerintahan daerah dalam membangun dan menata ruang kota dalam dimensi pembangunan berkelanjutan. Kota menjadi homogen dengan bangunan-bangunan yang sarat akan kepentingan ekonomi kapitalis seperti mall, pusat perdagangan, industri dan bangunan komersial lainnya yang hanya bisa diakses oleh minoritas yang memiliki kekuatan ekonomi dan politik. Implikasinya, ruang kota menjadi serba konsumtif dan hanya bisa dikendalikan oleh elit yang mempunyai akses kapital. Pengaturan tata ruang perkotaan kabupaten Gresik yang dipenuhi industriindustri besar menjadi salah satu pertanda bahwa tata ruang kota telah menjelma menjadi ajang hegemoni kapitalisme. Implikasinya pertumbuhan ekonomi yang sangat tinggi akibat topangan industrialisasi namun mencederai ekologi lingkungan dan sosial. Hal ini diperparah pula dengan realitas industri dan permukiman yang saling berdekatan.

Gagasan Harvey (2010) yaitu spatial fix adalah sebuah situasi atau kondisi yang dinamakan over akumulasi dengan ditandai adanya sebuah surplus kapital dan surplus 
Jurnal Pemikiran Sosiologi Volume 4 No. 1, Januari 2017

Galang Geraldy

Determinasi Kapitalisme Industri dalam Politik Penataan Ruang Perkotaan di Kabupaten Gresik

kekuatan tenaga kerja yang mengiringi sehingga memaksa kapitalis untuk melakukan ekspansi geografis dan reorganisasi spasial dengan jalan melakukan investasi di sektor proyekproyek jangka panjang. Harvey berusaha menempatkan produksi, reproduksi, dan rekonfigurasi ruang selalu menjadi pusat untuk memahami perkembangan kapitalisme. Bentuk kontemporer kapitalis sekarang ini, yaitu globalisasi tidak lebih dari perputaran lain dari produksi kapitalis dan rekonstruksi ruang. Menurutnya, segala proses itu memerlukan restrukturisasi geografis untuk aktivitas kapitalis di seluruh dunia. Determinasi kapitalisme membuat penataan ruang perkotaan kabupaten Gresik banyak dipenuhi ribuan industri-industri yang berkontribusi terhadap pertumbuhan ekonomi. Industriindustri sebagai manifestasi dari kapitalisme membutuhkan ruang untuk ekspansi produksi yang lebih besar dan hal ini memberikan dampak ekonomi yang tinggi terhadap kota sehingga tata ruang kota lebih dominan pada pembanguna industri dibanding dengan ruang-ruang bagi ekologi lingkungan. Banyak industriindustri global baik yang telah eksis maupun yang akan masuk berinvestasi di perkotaan kabupaten Gresik menjadi sebuah arena konstelasi ekonomi global. Strategi korporasi multinasional kerap tidak lagi memperhitungkan keberadaan ekonomi kota di negara asal mereka sendiri.
Pada akhirnya, pemindahan lokasi pabrik, gudang, pemasok dan pasar menyebabkan hancurnya pusat-pusat industri lama di negara-negara maju. Sebagai gantinya, bermunculan pusat-pusat komando baru dalam pasar keuangan internasional. Justru disinilah bentuk kelihaian kebijakan kapitalisme global dimana pabrik yang sarat akan polutan berada di kota-kota negara berkembang sedangkan di negara-negara maju hanya menyisakan kantor-kantor perusahaan sebagai pusat kebijakan. Salah satunya seperti halnya PT Eastern Australia yang akan membangun industrinya di Kabupaten Gresik. PT Eastern Pearl Flour Mills (EPFM), perusahaan dari Australia, akan membangun pabrik tepung terigu di Gresik. Investasinya sekitar Rp 300 miliar dengan kapasitas produksi sekitar 150 ribu ton per tahun. Walaupun secara spasial terpisah-pisah, pusat-pusat pengambilan keputusan di kota-kota global tetap bergantung pada keberadaan kota-kota besar di seluruh dunia, karena ke sanalah mereka memasarkan produk-produk yang mereka hasilkan (Sassen 1994).

Globalisasi ekonomi hanya dapat berfungsi melalui sebuah sistem jaringan antar-kota, sehingga untuk mewadahinya dibentuklah sejumlah pusat dan sub-pusat baru dengan kepadatan luar-biasa yang sering disebut sebagai Mega Cities. Dasar kekuatan kotakota tersebut tidak hanya pada kehadiran perusahaan-perusahaan besar. Kekuasaan 
Jurnal Pemikiran Sosiologi Volume 4 No. 1, Januari 2017

Galang Geraldy

Determinasi Kapitalisme Industri dalam Politik Penataan Ruang Perkotaan di Kabupaten Gresik

dan kontrol harus diciptakan, dan untuk dapat melakukannya korporasi-korporasi multinasional tidak bisa bekerja sendiri. Guna mengontrol para agen dan perkembangan pasar di seluruh dunia, di samping pusat-pusat perusahaan dan lembaga pelayanan keuangan, di kota-kota global bertumbuhan industri perkotaan yang baru, pelayanan konsultasi, kontrol, dan informasi. Saskia Sassen menamai tugas industri ini sebagai manajemen jarak jauh (long distance management), semacam pengendali jarak-jauh ekonomi dunia (Sassen 1994). Ideologi pembangunan dan penataan ruang kota yang merujuk pada pertumbuhan ekonomi tinggi memang menjadi tren model kebijakan yang beraras pada pemenuhan eksistensi ekonomi semata. Kapitalisme menjadi lakon dalam mengusung ide-ide pertumbuhan ekonomi, deregulasi pasar, liberalisasi politik, perdagangan bebas, swastanisasi pada sektor publik sampai persaingan secara langsung antara negara dengan pasar dalam melayani publik. Salah satunya adalah di kabupaten Gresik, dimana determinasi kapitalisme menjadi latar belakang berkembangnya industrialisasi di perkotaan kabupaten Gresik. Pemerintahan daerah memberikan keleluasaan bagi para pemodal untuk mendirikan industri-industri.

Selain Harvey dan Lefebvre, Edward Soja (1989) menjadi salah satu pemikir neomarxist yang berbicara banyak soal politik ruang. Soja sangat dipengaruhi oleh gagasan Foucault dan Lefebvre. Soja berusaha mengintegrasikan studi ruang dan geografi politik dengan studi waktu. Inti kontribusi teoritis Soja (1996, 2000) untuk pemahaman tentang ruang adalah gagasannya tentang trialektika (trialectics). Soja jelas membangun, mengembangkan, gagasan dialektika Marxian (dan Hegelian). Akan tetapi, sumber yang lebih dekat adalah karya Lefebvre, khususnya perbedaan antara praktik spasial, representasi ruang, dan ruang representasional.

Secara umum Lefebvre membuat perbedaan antara praktik material dan dua tipe ide tentang ruang. Soja menggunakan perbedaan dasar ini untuk menyusun teori yang disebut ruang-kota (cityspace). Salah satu trialektika Soja adalah perspektif First space yang pada dasarnya adalah berorientasi material yang konsisten dengan pendekatan yang sering diambil oleh ahli geografi dalam studi perkotaan. Soja (2000:10) mendeskripsikan pendekatan First space sebagai ruang-kota dapat dikaji sebagai seperangkat 'praktik sosial' yang dimaterialisasikan yang bekerja sama untuk memproduksi dan mereproduksi bentuk-bentuk konkrit dan pola-pola urbanisme spesifik sebagai gaya hidup. Industrialisasi dapat dipandang sebagai pratik materialisme perkotaan dimana terjadi pembangunan industriindustri yang 
Jurnal Pemikiran Sosiologi Volume 4 No. 1, Januari 2017

Galang Geraldy

Determinasi Kapitalisme Industri dalam Politik Penataan Ruang Perkotaan di Kabupaten Gresik

memicu pertumbuhan ekonomi sekaligus menciptakan sosial masyarakat yang konsumtif.

\section{Kesimpulan}

Konsep agrarian urbanism dalam smart growth memastikan bahwa permukiman, kota, dan wilayah mengakomodasi pertumbuhan dalam kerangka ekonomi, responsibilitas lingkungan, dan dukungan perkembangan kehidupan komunitas guna meningkatkan kualitas kehidupan (Genovese, 1998). Konsep ini bermula dari kelompok New Urbanism, yang muncul di Amerika Serikat sejak tahun 1980-an, yang menggagas bagaimana kota-kota harus dirancang dan ditata-ulang dengan lebih tetap berkarakter manusiawi, hubungan pertetanggaan tetap terjaga, dan tetap bisa berwawasan lingkungan. New Urbanism dipengaruhi secara kuat oleh standarstandar rancang kota sebelum bangkitnya industri dan konsumsi otomotif di pertengahan tahun 1920- an.

Dari gerakan New Urbanism ini, kemudian berkembang konsep-konsep pembangunan berbasis pola permukiman tradisional dan transit yang banyak diterapkan pada pembangunan real estate, perencanaan kota, dan strategi pemanfaatan lahan oleh pemerintah. Arsitek New Urbanist yang paling lantang mengeluarkan gagasan Agrarian Urbanism adalah Anders Duany (Ewing, Reid dan Clemente, 2013). Ia meletakkan konsep ini dalam sebuah konsep smart growth, yakni sebuah pembangunan yang merespon orientasi pasar dan sektor swasta dalam pembangunan wilayah. Duany menyebutkan, bahwa smart growth merupakan kolase antara New Urbanism, kebijakan pertumbuhan ekonomi, dan environmentalisme sejati.

Penelitian ini menunjukkan bahwa model pembangunan ruang perkotaan Gresik didominasi domain ekonomi (economic sentris) yang berbasis pada akumulasi modal industrialisasi. Ribuan industri besar, kecil maupun menengah terus beroperasi selama puluhan tahun yang secara langsung maupun tidak menyebabkan degradasi ekologi dan potensi yang membahayakan keselamatan warga perkotaan. Pemerintah daerah belum memiliki political will membangun perkotaan yang berdimensi pada aspek-aspek berkelanjutan seperti ekologi, sosial dan ekonomi secara berimbang. Sejatinya, pemerintah daerah perlu memikirkan untuk membangun ruang perkotaan yang berkonsep "agrarian urbanism" sebagai alternatif dalam perencanaan tata kelola ruang khususnya ketika wilayah tersebut terdampak oleh ekspansi perluasan industri yang kurang mempertimbangkan keseimbangan ekologi dan lingkungan sosial. 
Jurnal Pemikiran Sosiologi Volume 4 No. 1, Januari 2017

Galang Geraldy

Determinasi Kapitalisme Industri dalam Politik Penataan Ruang Perkotaan di Kabupaten Gresik

\section{Daftar Pustaka}

Ewing, Reid dan Otto Clemente. 2013. Measuring Urban Design: Metrics for Livable

Places Metropolitan Planning and Design: Washington. Island Press.

Genovese, Theresa, dkk. 1998. Civitas/What is city: California. Princeton Architectural

Press.

Harvey, David. 2010. Imperialisme Baru, Genealogi dan Logika Kapitalisme Kontemporer.Yogyakarta. Resist Book.

Husaini Usman, Purnomo Setiady Akbar. 1996. Metode Penelitian Sosial. Jakarta. Bumi Aksara: hal 74-80.

Lefebvre, Henri. 1991. The Production of Space. Translated by Donald Nicholson-Smith. Oxford: Blackwell.

Lefebvre, Henri. Critique of Everyday Life,. Trans. John Moore, London and New York,: Verso.2002.

Miles, MB dan AM Huberman. 1994. Qualitative Data Analysis: A Sourcebook of New Methods. Sage. Beverly Hills.

Massey, Dorren. A Global Sense of Place From Space, Place and Gender. Minneapolis : University of Minnesota Press, 1994.

Santoso, Jo. 2006. Menyiasati Kota Tanpa Warga: Jakarta. KPG dan Centropolis.

Sassen, Saskia. 1998. Globalization and Its Discontens. New York: The New Press.

Soja, Edward. 2010. Seeking Spatial Justice. Minneapolis: Minneapolis University Press.

Suyanto, Bagong dan Sutinah.2006. Metode Penelitian Sosial. Jakarta:Kencana Prenada Media Group.

V. Schneider, Eugene. 1986. Sosiologi Industri. Jakarta: Aksara Persada.
Disertasi:

Edy Lisdiyono. 2008. Legislasi Penataan Ruang; Studi tentang Pergeseran Kebijakan Hukum Tata Ruang dalam Regulasi Daerah di Kota Semarang. Disertasi. Semarang: Fakultas Hukum UNDIP

Dokumentasi Pemerintah:

Peraturan Daerah Nomor 2 DPRD-II/1974, tanggal 20 Maret 1974, dikuatkan oleh Peraturan Pemerintah Nomor 30 tahun 1974, tanggal 1 November 1974.

Kecamatan Dalam Angka (KDA) 2012. Bappeda Kabupaten Gresik.

Perda No. 8 Tahun 2011 tentang Rencana Detail Tata Ruang Kabupaten Gresik 20112030 